DOI: 10.30890/2567-5273.2018-05-03-020

УДК 641.85:613.2

NEW DESSERTS ARE IN CORRECTION OF DEFICIT OF IODINE AND

SELENIUM IN FEED OF POPULATION

НОВІ ДЕСЕРТИ У КОРЕКЦЇ̈ ДЕФЦЦИТУ ЙОДУ ТА СЕЛЕНУ

В ХАРЧУВАННІ НАСЕЛЕННЯ

Antonyuk I.Y./Антонюк I.Ю. c.t.s.as.prof./к.m.н., дои..

ORCID: http://orcid.org/0000-0003-4629-3403

Kyiv National University of Trade and Economics, Kyiv,Kioto 19, 02156 Київський національний торговельно-економічний університет, Київ, вул. Кіото 19, 02156

Korzun V.N./ Корзун B.H. d.m.s.prof./д,мед.н., проф.

Institute of public health the name of A.N. Marzeeva, National academy of medical sciences of Ukraine; Kyiv, Popudrenko 50, Kiev, 02660 Інститут громадського здоров'я ім. О.М. Марзеєва, Національної академї медичних наук України, Київ, Попудренка 50, 02660

Bondarenko K.V./Бондареко К.В. bachelor of speciality 181 «Food technologies»/ бакалавр спеціальності 181 «Харчові технології» Kyiv National University of Trade and Economics, Kyiv,Kioto 19, 02156 Київський національний торговельно-економічний університет, Київ, вул. Кіото 19, 02156

Анотація. В роботі наведено результати досліджень, спрямованих на розроблення нових технологій десертів із підвищеним вмістом мінеральних речовин, які можна використовувати в харчуванні дорослих і дітей з метою профілактики мікроелементозів, зокрема дефіциту йоду та селену. Розроблена технологія гарбузового суфле та чорничного шербету з використанням порошку иистозіри (продукт переробки морської водорості). Визначено рачіональну кількість добавки. Досліджено вміст основних мікроелементів (йоду, селену, ичику, заліза). Розраховано забезпечення добової потреби мікроелементів при споживанні розроблених десертів. Побудовано профіль якості чорничного десерту 3 використанням цистозіри.

Ключові слова: десерти, суфле, шербет, дефіųит йоду, дефіцичт селену, мікроелементи, циитозіра

Вступ. Серед харчових факторів, які мають особливо важливе значення для підтримування здоров'я, працездатності та активного довголіття людини, найважливішу роль відіграє повноцінне i регулярне забезпечення організму всіма необхідними мікронутрієнтами: вітамінами та життєво важливими мінеральними речовинами (макро- та мікроелементами). Вони необхідні для нормального обміну речовин, росту і розвитку організму, захисту від хвороб i шкідливих чинників зовнішнього середовища, надійного забезпечення всіх життєвих функцій. [1,2]

Повсякденний раціон більшості населення України в останні 15-20 років, в основному, вуглеводно-жировий, з недостатньою кількістю тваринного білка, 
дефіцитом вітамінів і мікроелементів. Результати популяційних досліджень свідчать про вкрай незадовільне споживання і зростаючий дефіцит вітамінів (А, групи В, C, Е) і мікроелементів (заліза, цинку, йоду, селену) у значної частини населення. Виявлений дефіцит найчастіше носить характер поєднаної вітамінно-мінеральної недостатності $[3,4]$.

Йод виконує надзвичайно важливу функцію в організмі людини. Дефіцит йоду безпосередньо пов'язаний 3 харчуванням, iз недостатнім вмістом йодовмісних продуктів та білку. Також несприятливу роль в розвитку йоддефіцитних захворювань за останні роки відіграли значні зміни в характері харчування: в 3 рази знижено споживання морської риби та морепродуктів, багатих йодом, а також м'яса і молочних продуктів, в яких вміст йоду відносно високий. [3, 5, 6]

Основний текст. Світовий та вітчизняний досвід засвідчує, що найбільш ефективним і доцільним 3 економічної і технологічної точок зору заходом кардинального вирішення проблеми є розробка і налагодження виробництва різноманітних спеціальних харчових продуктів, додатково збагачених дефіцитними (в раціонах харчування) нутрієнтами. При цьому, недоцільно збагачувати продукт лише одним, найбільш дефіцитним нутрієнтом [7].

Мета роботи - розроблення технології десертів із покращеним нутрієнтним складом, а саме суфле та шербету.

Матеріали та методи. Об’єкт дослідження - технологія десертів із покращеним нутрієнтним складом із використанням порошку цистозіри (ТУ У 21663408.001-2006).

В основу розробленої технології покладено завдання вдосконалення технології виробництва десертів із використанням цистозіри (ТУ У 21663408.001-2006). Це дає можливість отримання десертів із підвищеним вмістом йоду та селену, а також інших молекулярних синергістів йоду (цинк, залізо). За контрольний зразок обрано страви, виготовлені за традиційними технологіями.

Органолептичну оцінку страв проведено за розробленою 5-баловою шкалою $з$ урахуванням коефіцієнтів вагомості окремих показників. Вміст мінеральних речовин визначено атомно-абсорбційним методом на спектрофотометрі Techtron-AA-4 (Австрія), Йоду - методом інверсійної вольтамперометрії (прилад АВА-3, Росія) [8]. Повторюваність дослідів п’ятикратна.

Результати дослідження. Вибір об’єктів дослідження враховує найбільш популярні види десертів, як серед дорослих, так й дітей. Вибір сировини грунтувався на дослідженні наявності в ऑii складі важливих фізіологічно функціональних інгредієнтів, враховуючи перспективу корегування хімічного складу страв у напрямі насичення мінеральними речовинами.

Суфле (від фp. suffle - пухкий, повітряний пиріг). Збиті в піну напіврідкі або тонко розтерті в пудру харчові продукти. Суфле частіше за все готують 3 яєць 3 різними ароматичними добавками. Існує три основних види суфле: запечене, охолоджене та заморожене. Для подальших досліджень було обрано охолоджене суфле, оскільки запікання при температурі вище $180^{\circ} \mathrm{C}$ негативно 
впливає на вміст вітамінів і мінеральних речовин, особливо йоду та селену.

Шербет готують на основі фруктового або ягідного пюре. Він обов'язково містить молоко або вершки, а іноді яйця. Цей десерт нагадує фруктове морозиво. В якості основної сировини для суфле було використано гарбуз, а для шербету - чорницю.

Гарбуз - цінний овоч для дієтичного харчування через високий вміст пектинових речовин (2.6-3.9 \%), каротиноїдів (3.2-17.3 мг/100 г), зокрема таких як лютеїн, лікопін, $\beta$-каротин, $\beta$-криптоксантин. За вмістом $\beta$-каротину він перевищує інші овочі (14.0-35.0 мг/100 г) і має невелику енергетичну цінність (28 ккал/100 г), і тому його включають у значну кількість дієт [9].

Чорниця - унікальна за своїм складом ягода, яка містить величезну кількість різних вітамінів і мікроелементів, що необхідні для правильної роботи нашого організму. До складу ягід чорниці входять цукри (до 6\%), лимонна, яблучна, молочна, бурштинова, щавлева, хінна кислоти (1-1,2\%), глюкозид гліконін, барвник міртилін, дубильні та пектинові речовини, мінеральні солі, вітаміни А, C, $\mathrm{B}_{1}, \mathrm{~B}_{2}$, РP, макро- та мікроелементи (залізо, манган, селен, кобальт, мідь, золото, срібло, цинк). [10]

Вміст цистозіри визначали, виходячи 3 того, що запропонована кількість добавки не повинна погіршувати органолептичні показники готових страв, й в той же час - забезпечувати від 30-60\% добової потреби в йоді та селені. На підставі проведених досліджень визначено раціональну кількість добавки, яка становить $0,7 \%$ від маси готової страви або 1 г на 150 г десерту (стандартний вихід порції).

Загальну органолептичну оцінку розроблених десертів визначено як суму окремих органолептичних показників у балах (зовнішній вигляд, колір, консистенція, запах, смак) 3 урахуванням коефіцієнтів вагомості кожного показника в загальній якості. При проведенні дегустації визначено, що органолептичні показники дослідних десертів знаходяться в межах контролю (шербет: контроль - 4.90, дослід - 4.92; суфле: контроль - 4.83, дослід - 4.87).

За результатами експериментальних досліджень розроблено технологію виробництва десертів. Приклад розробленої технології для десерту «Прованс» (чорничний шербет) наведено на рисунку 1.

Мікроелементний склад розроблених десертів із покращеним нутрієнтним складом наведено в таблиці 1.

Біологічна цінність десертів із покращеним нутрієнтним складом, а саме шербету та суфле, зросла щодо Феруму - на 5.2 та 3.9\%, Йоду - в 9.4 та 12.1 разів і Селену - в 65 та 30 разів відповідно.

Забезпечення добової потреби у мікроелементах при споживанні розроблених десертів наведено у таблиці. 2.

За визначеними показниками побудовано профілограму мінерального складу десерту «Прованс» із використанням цистозіри за допомогою пакета EXCEL 97 WINDOWS (рис. 2). Профілограма мінерального складу гарбузового суфле «Золотавий промінь» подібна до профілографи десерту «Прованс».

Форма наведених профілограм має вигляд п'ятикутників, вершинами яких є визначені мінеральні речовини досліджуваних страв, що прийняті за $30 \%$ 


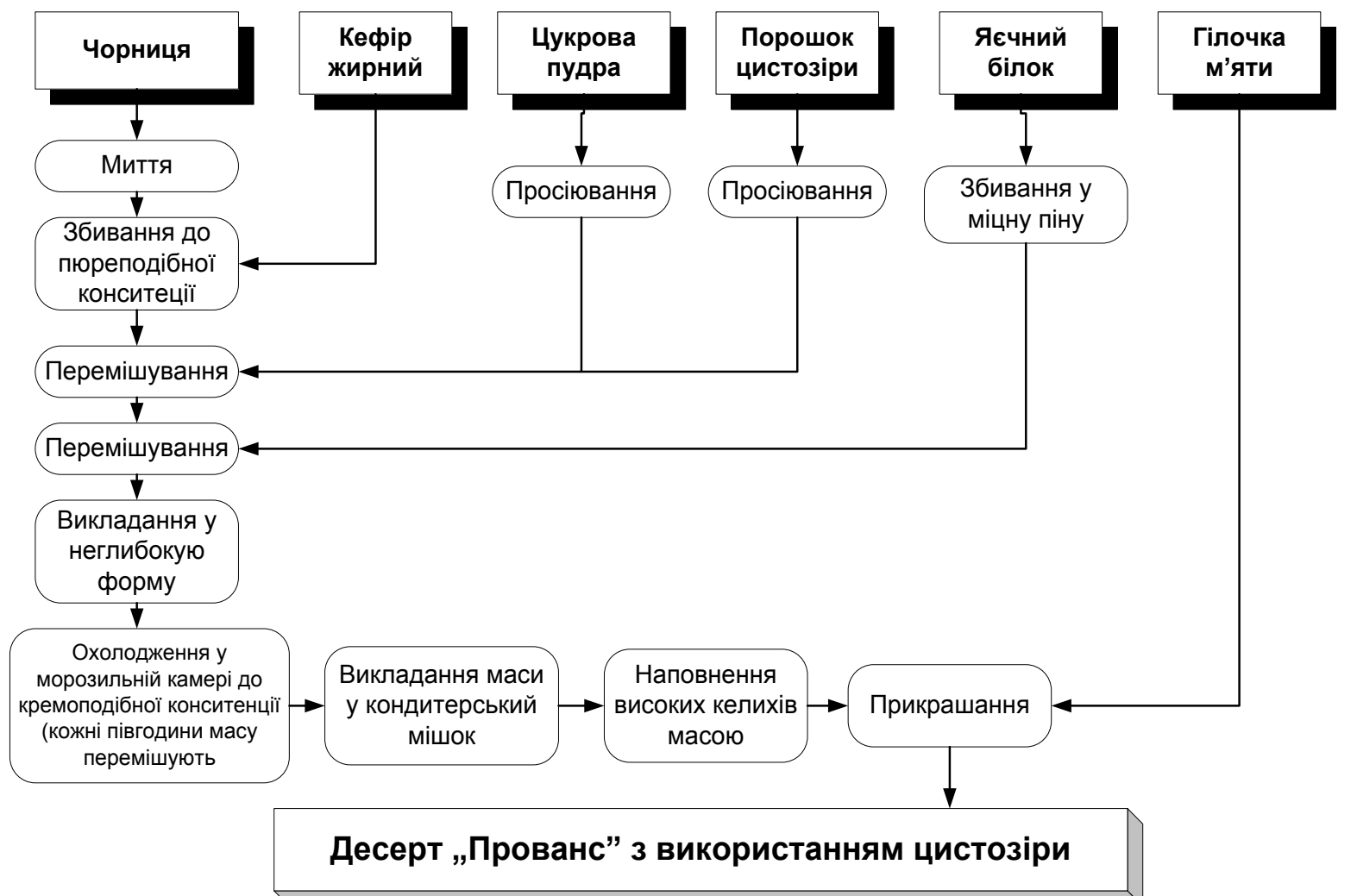

Рис. 1 Технологічна схема виробництва десерту «Прованс» (чорничний шербет) із використанням цистозіри Авторська розробка

Таблиця 1

Мікроелементний склад десертів із покращеним нутріснтним складом мкг/150 г

\begin{tabular}{|c|c|c|c|c|c|c|}
\hline \multirow[t]{2}{*}{ Речовина } & \multicolumn{3}{|c|}{ Шербет чорничний } & \multicolumn{3}{|c|}{ Суфле гарбузове } \\
\hline & контроль & $\begin{array}{c}\text { дослід } \\
\text { десерт } \\
\text { «Прованс» }\end{array}$ & $\begin{array}{c}\text { різни-ця } \\
\text { з конт- } \\
\text { ролем, } \\
\%\end{array}$ & контроль & $\begin{array}{c}\text { дослід } \\
\text { суфле } \\
\text { «Золотави } \\
\text { й промінь» }\end{array}$ & $\begin{array}{c}\text { різни- } \\
\text { ця } 3 \\
\text { конт- } \\
\text { ролем, } \\
\%\end{array}$ \\
\hline Ферум & $\begin{array}{c}5600.0 \pm \\
100.0\end{array}$ & $\begin{array}{c}5890,0 \pm \\
100.0\end{array}$ & 5.2 & $\begin{array}{c}950.0 \pm \\
80.0\end{array}$ & $\begin{array}{c}987.0 \pm \\
80.0\end{array}$ & 3.9 \\
\hline Йод & $16.0 \pm 0.10$ & $150.0 \pm 4.0$ & $\begin{array}{l}\text { у } 9.4 \\
\text { рази }\end{array}$ & $9.0 \pm 0.10$ & $109.0 \pm 4.0$ & $\begin{array}{c}\text { у } 12.1 \\
\text { разів }\end{array}$ \\
\hline Цинк & $202.0 \pm 10.0$ & $216.0 \pm 10.0$ & 6.9 & $\begin{array}{c}527.0 \pm \\
10.0\end{array}$ & $\begin{array}{c}541.0 \pm \\
10.0\end{array}$ & 2.7 \\
\hline Селен & $1.0 \pm 0.10$ & $65.0 \pm 2.0$ & $\begin{array}{l}\text { у } 65 \\
\text { разів }\end{array}$ & $2.0 \pm 0.10$ & $60.0 \pm 1.0$ & $\begin{array}{c}\text { у } 30 \\
\text { разів }\end{array}$ \\
\hline
\end{tabular}

\section{Авторська розробка}

задоволення добової потреби населення. Профілі якості розроблених десертів мають більшу площу поверхні порівняно з контрольним зразком, а за вмістом йоду та селену перевищують еталон, оскільки задовольняють добову потребу у цих речовинах на 100.0-72.7 та 85.7.-92.9\% відповідно [11]. 
Таблиця 2

Забезпечення добової потреби мікроелементів при споживанні людиною десертів із покращеним нутріснтним складом (150 г)

\begin{tabular}{|l|c|c|c|c|c|}
\hline \multirow{2}{*}{ Вміст речовин } & \multirow{2}{*}{$\begin{array}{c}\text { Добова } \\
\text { потреба }\end{array}$} & $\begin{array}{c}\text { Контроль } \\
\text { шербет }\end{array}$ & $\begin{array}{c}\text { Десерт } \\
\text { «Прованс» }\end{array}$ & $\begin{array}{c}\text { Контроль } \\
\text { суфле }\end{array}$ & $\begin{array}{c}\text { Суфле } \\
\text { «Олотавий } \\
\text { промінь» }\end{array}$ \\
\hline Ферум, мг & 15 & 37.3 & 39.3 & 6.3 & 6.58 \\
\hline Цинк, мг & 15 & 1.35 & 1.44 & 3.5 & 3.6 \\
\hline Йод, мкг & 150 & 10.1 & 100 & 6.0 & 72.7 \\
\hline Селен, мкг & 70 & 1.42 & 92.9 & 2.9 & 85.7 \\
\hline
\end{tabular}

Авторська розробка

На розроблені десерти отримано патенти України на корисну модель: Патент №119733 від 10.10 .17 р. Спосіб виробництва десерту «Прованс» 3 використанням цистозіри; Патент №128185 від 10.09.18 р. Спосіб виробництва гарбузового суфле «Золотавий промінь» 3 використанням цистозіри.

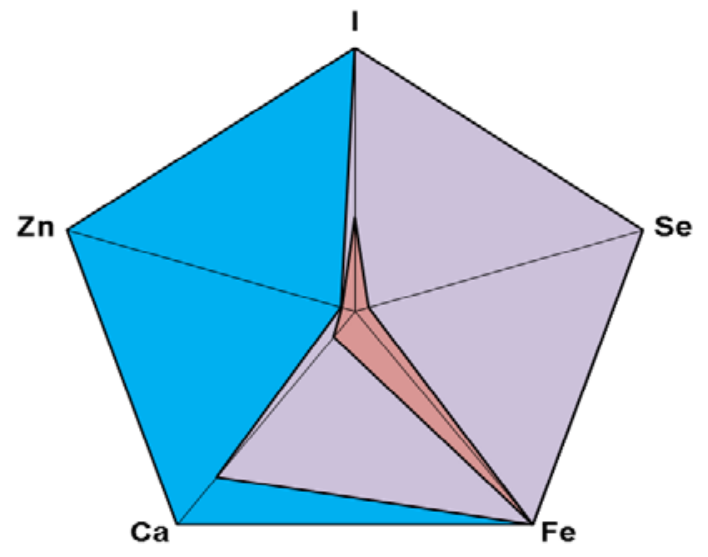

口Еталон
вДослід
口Контроль

Рис. 2. Профіль мінерального складу десерту "Прованс " Авторська розробка

Висновки. Використання цистозіри дозволяє створити нові десерти 3 покращеним нутрієнтним складом, 3 підвищеним вмістом йоду та селену. Соціальний ефект полягає у розширенні асортименту конкурентопридатних десертів. Розроблені десерти 3 підвищеним вмістом йоду та селену можна рекомендувати всім віковим групам (за винятком немовлят) населення України в межах фізіологічних норм замість їх традиційних аналогів.

Література:

1. Микронутриенты в питании здорового и больного человека / [Тутельян В.А., Спиричев В.Б., Суханов Б.П., Кудашева В.А.]. - М. : Колос, 2002. $424 \mathrm{c}$.

2. Батурин А. К., Мендельсон Г. И. Питание и здоровье: проблемы XXI века. Пищ. пром-ть. 2005. № 5. С. 105-107.

3. Причины изменений в структуре питания современного человека. 


\section{Здоровье и организм: полезные советы. - Режим доступа:} http://opportunity.com.ua/teoriya/prichiny-izmenenij-v-strukture-pitaniyasovremennogo-cheloveka.html.

4. Смоляр В. І. Основні тенденції в харчуванні населення України / В. І.Смоляр // Проблеми харчування. — 2007. — № 4 (17). — С. 5-10.

5. Маменко М.С. Нераціональне харчування як передумова формування дефіциту йоду та заліза у дітей / М.Є. Маменко// Перинатологія та педіатрія. 2008. № 3 (35). - С. 86-90.

6. Аметов А.С. Элементный дисбаланс при патологии щитовидной железы /А.С. Аметов, С.А. Рустамбекова, А.М. Плиашинова// Русск. мед. ж. - 2008, T.16, № 16. - C.8-13.

7. Нові підходи у вирішенні проблеми ліквідації йоддефіцитних захворювань / Корзун В. Н., Парац А. М., Бруслова К. М. та ін. // Проблеми харчування. - 2004. - № 3. - С. 21-25.

8. Tomcik P. Voltammetric determination of iodide by use of an investigated microelectrode array / P. Tomcik, D. Bustin // Fresenius J. Anal. Chem. — 2001. Vol. 371. - P. 362-364.

9. Полезные и лечебные свойства тыквы для здоровья - Режим доступу: http://opolze.net/svoistva/ovoshhi/tykva.html

10. Калорийность Черника. Химический состав и пищевая ценность. Режим доступу: https://health-diet.ru/base of food/sostav/433.php

11.Мазаракі А.А., Пересічний М.I., Шаповал С.Л., Бай С.I., Чаюн I.O., Расу лов Р.А., Григоренко О.М., Литвиненко Т.С., Антонюк I.Ю., Тарасенко I.I. Проектування закладів ресторанного господарства: навч. посіб. 2-ге вид., переробл. та доповн. Київ: Київ. нац. торг.-екон. ун-т., 2010. 339 с.

\section{References:}

1. Tutel'yan V., Spirichev V., Sukhanov B., Kudasheva V. (2002). Mikronutrienty v pitanii zdorovogo i bol'nogo cheloveka [Mikronutrienty is in the feed of healthy and sick man], Kolos, Moscow, 424 p.

2. Baturin A.K., Mendel'son G.I. (2005).Pitanie i zdorov'e: problemy XXI veka Feed and health: problems of XXI century], in Xarchova promy`slovist ' [Food industry] No.5, pp.105-107.

3."Prichiny izmenenij v strukture pitaniya sovremennogo cheloveka. Zdorov'e i organizm: poleznye sovety"[Reasons of changes are in the structure of feed of modern man. Health and organism: useful advices], vailable at: http://opportunity.com.ua/teoriya/prichiny-izmenenij-vstrukture-pitaniya-sovremennogo-cheloveka.html

4. Smolyar V.I. (2007). Osnovni tendenciyi v xarchuvanni naselennya Ukrayiny`Basic tendencies are in the feed of population of Ukraine] in Problemy`xarchuvannya [Problems of feed]. No.4 (17), pp. 5-7.

5.Mamenko M.Ye. (2008). Neracional`ne xarchuvannya yak peredumova formuvannya deficy tu jodu ta zaliza u ditej [Children have an inefficient feed as pre-condition of forming of deficit of iodine and iron] in Pery`natologiya ta pediatriya [Obstetrics and pediatrics]. No.3 (35), pp. 86-90.

6. Ametov A.S., Rustambekova S.A., Pliashinova A.M.(2008). Ehlementnyj disbalans pri patologii shchitovidnoj zhelezy [Element disbalance at pathology of thyroid] in Russkij medicinskij zhurnal [Russian medical magazine]. vol.16. No.16, pp. 8-13.

7.Korzun V.N., Parats A.M., Brusilova K.M. (2004). Novi pidxody` u vy`rishenni problemy likvidaciyi joddeficy`tny`x zaxvoryuvan` [New approaches are in the decision of problem of liquidation of йоддефіцитних diseases] in Problemy` хаrchuvannya [Problems of feed]. No.3, pp. 
21-25.

8. Tomcik P. (2001). Voltammetric determination of iodide by use of an investigated microelectrode array / P. Tomcik, D. Bustin // Fresenius J. Anal. Chem. - Vol. 371. - P. 362-364.

9. Poleznye i lechebnye svojstva tykvy dlya zdorov'ya [Useful and curative properties of pumpkin for a health], vailable at: http://opolze.net/svoistva/ovoshhi/tykva.html.

10. Kalorijnost' CHernika. Himicheskij sostav i pishchevaya cennost'. [Calorie content. Whortleberry. Chemical composition and food value], vailable at:_https://healthdiet.ru/base_of_food/sostav/433.php

11. Mazaraki A.A., Peresichnyj M.I., Shapoval S.L., Baj S.I., Chayun I.O., Rasulov P.A., Grigorenko O.M., Litvinenko T.Ie.,Antonyuk I.Yu., Tarasenko I.I. (2010). Proektuvannya zakladiv restorannogo gospodarstva: navch. posib. 2-ge vid., pererobl. ta dopovn. Kiïv: Kiïv. nac. torg.ekon. un-t. [Planning of establishments of restaurant economy], $339 \mathrm{p}$.

Abstract. Raising of problem. The deficit of iodine is directly related to the feed, with insufficient content of iodic products. World and home experience certifies that the most effective and expedient event of cardinal decision of problem are development and adjusting of production of the various special food products additionally enriched by scarce (in the rations of feed) substances. Thus, beside the purpose to enrich a product only by one most scarce substance

An aim of work is development of technology of desserts with the improved microelement composition, namely to the soufflé and sherbet.

Materials and methods. A research object is technology of desserts with the improved microelement composition with the use of powder of cistozira (TU 21663408.001-2006). For a control standard the foods made after traditional technologies are select.

The organoleptic estimation of foods is conducted after developed by a 5-ball by a scale taking into account the coefficients of importance of separate indexes. Content of mineral matters is certain an atomno-absorbciynim method on the spectrophotometer of Techtron-aa-4 (Austria), to Iodine - by the method of inversion vol'tamperometrii (device of AVA-3, Russia). Repetition of experiments is fivefold.

Research results. The choice of research objects takes into account the most popular types of desserts, both among adults and children. A choice of raw material was based on research of presence in her composition of important physiologically functional ingredients, taking into account the prospect of change of chemical composition of foods in the direction of satiation mineral substances. For further researches a pumpkin soufflé and whortleberry sherbet are select.

Content of cistoziri was determined, coming from that the offered amount of addition must not worsen the organoleptic indexes of the prepared foods, and at the same time - to provide from a 30$60 \%$ day's requirement in an iodine and selenium. On the basis of the conducted researches certainly rational amount additions which makes $0,7 \%$ from mass of the prepared food or a 1 gramme on 150 grammes of sweet food (standard output of portion).

On the basis of experimental researches the substantial increase of content of iodine and selenium is fixed in the worked out desserts. The biological value of desserts with the improved microelement composition, namely to the sherbet and soufflé, grew in relation to Iron - on 5.2 and 3.9\%, to Iodine - in 9.4 and 12.1 times and Selene - in 65 and 30 times accordingly.

On the worked out desserts the patents of Ukraine are got on an useful model: Patent №119733 from 10.10.17. Method of production of dessert "Provence" with the use of cistozira; Patent №128185 from 10.09.18 Method of production of pumpkin souffle the "Goldish ray" with the use of cistozira.

Conclusions. The worked out desserts with enhanceable maintenance of iodine and selenium it can recommend all age-related groups (except for babies) of population of Ukraine within the limits of physiology norms instead of their traditional analogues.

Key words: desserts, soufflés, sherbet, deficit of iodine, deficit of selenium, microelements, cistozira.

Статья отправлена: 11.10.2018 г.

Антонюк И.Ю. 